\title{
Кольский редкометалльный пегматитовый пояс: основные черты геологического строения
}

\author{
Морозова Л.Н., Серов П.А., Кунаккузин Е.Л., Борисенко Е.С., Сидоров М.Ю., Иванов А.Н.
} Геологический институт КНЦ РАН, Anamumbl,morozova@geoksc.apatity.ru

Аннотация. В статье кратко освещается геологическое строение пегматитовых полей Кольского редкометалльного пегматитового пояса. Как и пояса редкометалльных пегматитов мира, этот пояс включает редкометалльные месторождения, редкометалльные пегматиты и безрудные пегматиты. Он пространственно связан с зоной сочленения архейских Мурманской и Кольской провинций на северо-востоке Фенноскандинавского щита. Эта линейная структура интерпретируется как транскоровая зона сдвигового течения архейского заложения, испытавшая активизацию в палеопротерозое. Она служила подводящим каналом для рудоносных флюидов, сформировавших пегматитовые поля и месторождения редкометалльных пегматитов: Васин-Мыльк (Cs), Олений хребет (Тa), Охмыльк (Cs-Ta), Полмостундровское (Li), Колмозерское (Li) и Шонгуйское $(\mathrm{Be})$.

Ключевые слова: редкометалльные пегматиты, литий, цезий, бериллий, Кольский регион, Фенноскандинавский щит.

\section{The Kola Rare-Metal Pegmatite Belt: main features of the geological structure}

\author{
Morozova L.N., Serov P.A., Kunakkuzin E.L., Borisenko E.C., Sidorov M.Yu., Ivanov A.N. \\ Geological Institute KSC RAS, Apatity,morozova@geoksc.apatity.ru
}

Abstract. The article shortly considers the geological structure of pegmatite fields of the Kola Rare-metal Pegmatite Belt. As rare-metal pegmatite belts throughout the world, the belt consists of rare-metal deposits, raremetal pegmatites, and ore-free pegmatites. It is located in the transitional zone between the Archean Murmansk and Kola provinces in the northeastern Fennoscandian Shield. This linear structure is interpreted as a transcrustal shear zone formed in the Archean and reactivated in the Paleoproterozoic. It operated as a channel for ore-forming fluids that formed the pegmatite fields and deposits of rare-metal pegmatites: Vasin-Mylk (Cs), Oleny Ridge (Ta), Okhmylk (Cs-Ta), Polmostundra (Li), Kolmozero (Li), and Shongui (Be).

Key words: rare-metal pegmatite, Kola region, lithium, cesium, beryllium, Kola region, Fennoscandian Shield.

\section{Введение}

Крупные промышленные месторождения связаны с пегматитовыми поясами, в которых редкометалльные пегматиты ассоциируют с пегматитовыми жилами без редкометалльной минерализацией (Загорский и др., 1997, и ссылки там). Так, например, крупное литиевое месторождение Вейнебене (Австрия) расположено в Альпийской зоне пегматитов, в которой часть пегматитовых жил не несет редкометалльной минерализации. Пегматитовый пояс Монгольского Алтая содержит месторождение редкометалльных пегматитов Коктогай и, кроме редкометалльных пегматитовых жил, также содержит жилы слюдоносных и безрудных пегматитов. Аналогичными примерами служат Нуристанский, Гиндукушский и Бадахшанский редкометалльные пегматитовые пояса Афганистана, в которых преобладают пегматиты петалит-сподуменового типа, но встречаются и безрудные пегматитовые тела. При этом, например, Нуристанский пегматитовый пояс содержат семь редкометалльных месторождений пегматитов. В России - это Восточно-Саянский редкометалльный пегматитовый пояс длиной до 500 км при ширине от 40 до 70 км, который состоит из редкометалльных и безрудных пегматитов и вмещает Гольцовое, Белореченское и Урикское месторождения сподуменовых пегматитов в его восточной части и Вишняковское месторождение - в северо-западной части. Южно-Сангиленский редкометалльный пегматитовый пояс протяженностью более 120 км содержит Тастыгское месторождение сподуменовых пегматитов. Отличительной чертой этого месторождения является обогащение пегматитов не только $\mathrm{Nb}, \mathrm{Sn}, \mathrm{Be}$ и Та, что типично для пегматитов 
сподуменового типа, но и REE, Y, U, Zr, Hf и $\mathrm{Pb}$. Восточно-Забайкальский редкометалльный пегматитовый пояс вмещает Завитинское месторождение, которое было единственным разрабатывавшимся в России месторождением (Загорский и др., 1997; Загорский и др., 2014).

В Кольском регионе расположен Кольский редкометалльный пегматитовый пояс (КРПП), основные черты геологического строения которого излагаются в данной статье. Строение КРПП рассматривается на основе авторских материалов, собранных при изучении пегматитовых полей: Колмозерского, Солдат-Мыльковского, Поросозерского, Полмостундровского, Васин-Мыльк, Охмыльк и Шонгуйского, а также литературных данных.

\section{Результаты исследований}

КРПП простирается от оз. Кальмозеро к северо-западу почти до границы с Норвегией и имеет длину более 300 км при ширине от 20 до 45 км. В этом поясе сосредоточены до 95\% жил пегматитов с редкометалльной минерализацией (Be, Ta, $\mathrm{Nb}, \mathrm{Cs}, \mathrm{Li})$, выявленных на Кольском полуострове (Мультимедийный..., 2001). КРПП пространственно совпадает с зоной сочленения архейских Мурманской и Кольской провинций (рис. 1 a). Эта линейная структура давно рассматривается как мобильно-проницаемая зона, заложенная в архее и частично активизированная в палеопротерозое (Земная кора..., 1978). В русскоязычной литературе такие линейные структуры описывались как глубинные разломы. В современных концепциях структурной геологии и тектоники литосферных плит они интерпретируются как транскоровые зоны сдвигового течения (shear zones) на границах крупных блоков земной коры или литосферных плит. Вследствие своей проницаемости они являются каналами, по которым циркулируют рудоносные флюиды, при этом рудные компоненты осаждаются не только внутри этих зон, но и в их бортах (Fractures..., 1999).

Значительную часть зоны сочленения Мурманской и Кольской провинций занимает архейский зеленокаменный пояс Коломозеро-Воронья, и именно в нем локализовано большинство пегматитовых полей (ПП) - Поросозерское, Солдат-Мыльковское, Полмостундровское, Олений хребет, Охмыльк и Васин-Мыльк (рис. 1 б). В непосредственной близости от зоны сочленения находятся еще два пегматитовых поля - Шонгуйское в Кольской провинции (рис. 1 а) и Колмозерское в Мурманской (рис. 1 б).

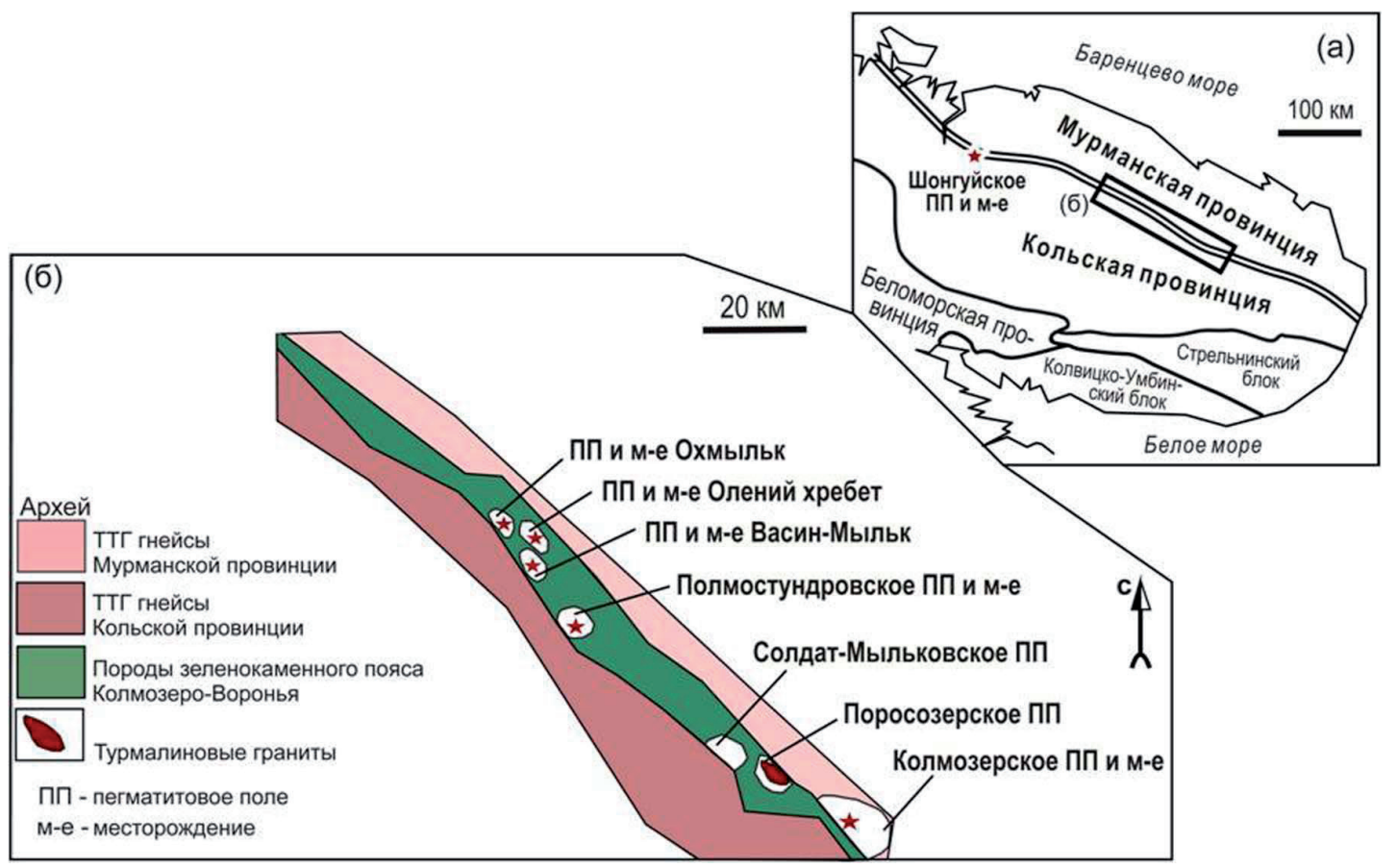

Рис. 1. Схемы расположения редкометальных месторождений и пегматитовых полей в структуре Кольского региона (а) и зеленокаменном поясе Колмозеро-Воронья (б).

Fig. 1. Scheme of the location of pegmatite fields and rare-metal deposits in the Kola rare-metal pegmatite belt. 
Колмозерское ПП имеет протяженностью 20 км при ширине $\sim 15$ км, расположено от Мурманской провинции в непосредственной близости от зеленокаменного пояса Колмозеро-Воронья и ограничено с C-3 и Ю-В Колмозерским и Иоканьгским разломами соответственно (рис. 1). В этом пегматитовом поле расположено Колмозерское месторождение альбит-сподуменовых пегматитов с $\mathrm{Be}-\mathrm{Ta}-\mathrm{Nb}$-Li минерализацией, а также мусковит-полевошпатовые пегматиты с Be-Nb-Ta минерализацией и полевошпатовые пегматиты с Ве минерализацией. Альбит-сподуменовые пегматиты залегают в архейских метагаббро-анортозитах Патчемварекского массива, мусковит-полевошпатовые - в аналогичных породах массива Безымянный, а полевошпатовые - в архейских метагранодиоритах Колмозерского массива, архейских гранитогнейсах и метагаббро-анортозитах массива Северный (Гордиенко, 1970).

Колмозерское месторождение является одним из самых крупных месторождений лития в России. Оно включет 12 крупных и многочисленные мелкие плитообразные жилы альбит-сподуменовых пегматитов с апофизами, раздувами и пережимами. Крупные жилы имеют длину более 1400 м, мощность от 5 до 65 м и прослеживаются на глубину более 500 м. Основным минералом лития является сподумен (рис. 2 a) с содержанием в породе $20 \%$. Берилл и минералы группы колумбита являются акцессорными минералами, но при значительных объемах жил они представляют промышленный интерес как сырье на $\mathrm{Be}, \mathrm{Ta}$ и $\mathrm{Nb}$. Альбит-сподуменовые пегматиты секутся дайками габбродолеритов предположительно палеозойского возраста. Колмозерское месторождение осложнено сбросом северо-западного простирания (Гордиенко, 1970). U-Pb возраст колумбита-(Mn) составляет $2315 \pm 10$ млн лет и интерпретируется как возраст редкометалльных пегматитов (Морозова и др., 2017). Этот возраст предполагает образование этих пегматитов в условиях растяжения земной коры во время раннепалеопротерозойского рифтинга Фенноскандинавкого щита.

Поросозерское ПП залегает в породах зеленокаменного пояса Колмозеро-Воронья рядом с его тектонической границей с Мурманской провинцией примерно в 20 км к северо-западу от Колмозерского месторождения (рис. 1). Это пегматитовое поле включает жилы пегматитов с Ве-Та минерализацией и жилы безрудных пегматитов. В центральной части поля располагается массив турмалиновых лейкогранитов с возрастом 2.73 млрд. лет (Кудряшов и др., 2017), которые при повышенном содержании $\mathrm{Li}, \mathrm{Nb}$ и Та не содержат рудных минералов и практического интереса не представляют (Гордиенко, 1970).

Солдат-Мыльковское ПП представлено редкометалльными альбит-сподуменовыми пегматитами с Be-Ta-Nb-Li минерализацией и полевошпатовыми пегматитами с Be-Ta-Nb минерализаций, прорывающими породы зеленокаменного пояса Колмозеро-Воронья рядом с его юго-западной тектонической границей с Кольской провинцией (рис. 1). Самая крупная жила альбит-сподуменовых пегматитов имеет длину 400 м при мощности от 45 до 85 м и прорывает гранатовые амфиболиты зеленокаменного пояса. Жилы полевошпатовых пегматитов имеют длину 50-150 м при видимой мощности 10-20 м и в промышленном отношении интереса не представляют (Гордиенко, 1970; Морозова, 2019).

Полмостундровское ПП расположено в юго-западной краевой части зеленокаменного пояса Колмозеро-Воронья рядом с его тектонической границей с Кольской провинцией (рис. 1). В этом поле выделяют три типа пегматитов: (а) редкометалльные пегматиты с Be-Ta-Nb-Li минерализацией, образующие Полмостундровское месторождение, (б) кварц-полевошпатовые пегматиты с бериллом и минералами группы колумбита и (в) безрудные кварц-полевошпатовые пегматиты. Одна из кварц-полевошпатовых жил имеет концентрически зональное строение и содержит сподумен, но не представляет промышленного интереса. Вмещающими для пегматитов различного типа являются разные породы зеленокаменного пояса, но жилы редкометалльных пегматитов Полмостундровского месторождения залегают только в амфиболитах полмостундровской свиты.

В Полмостундровском месторождении главным породообразующим минералом и соответственно основным минералом лития является сподумен (рис. 2 б), на долю которого приходится $\sim 20$ \% объема жил. При разработке этого месторождения промышленный интерес могут представлять берилл и минералы группы колумбита. Протяженность жил редкометалльных пегматитов месторождения составляет 1500-1900 м при ширине выхода 40 м. Жилы имеют плитообразную форму и осложнены раздувами и пережимами. Концентрическая зональность в пегматитоввх жилах от- 


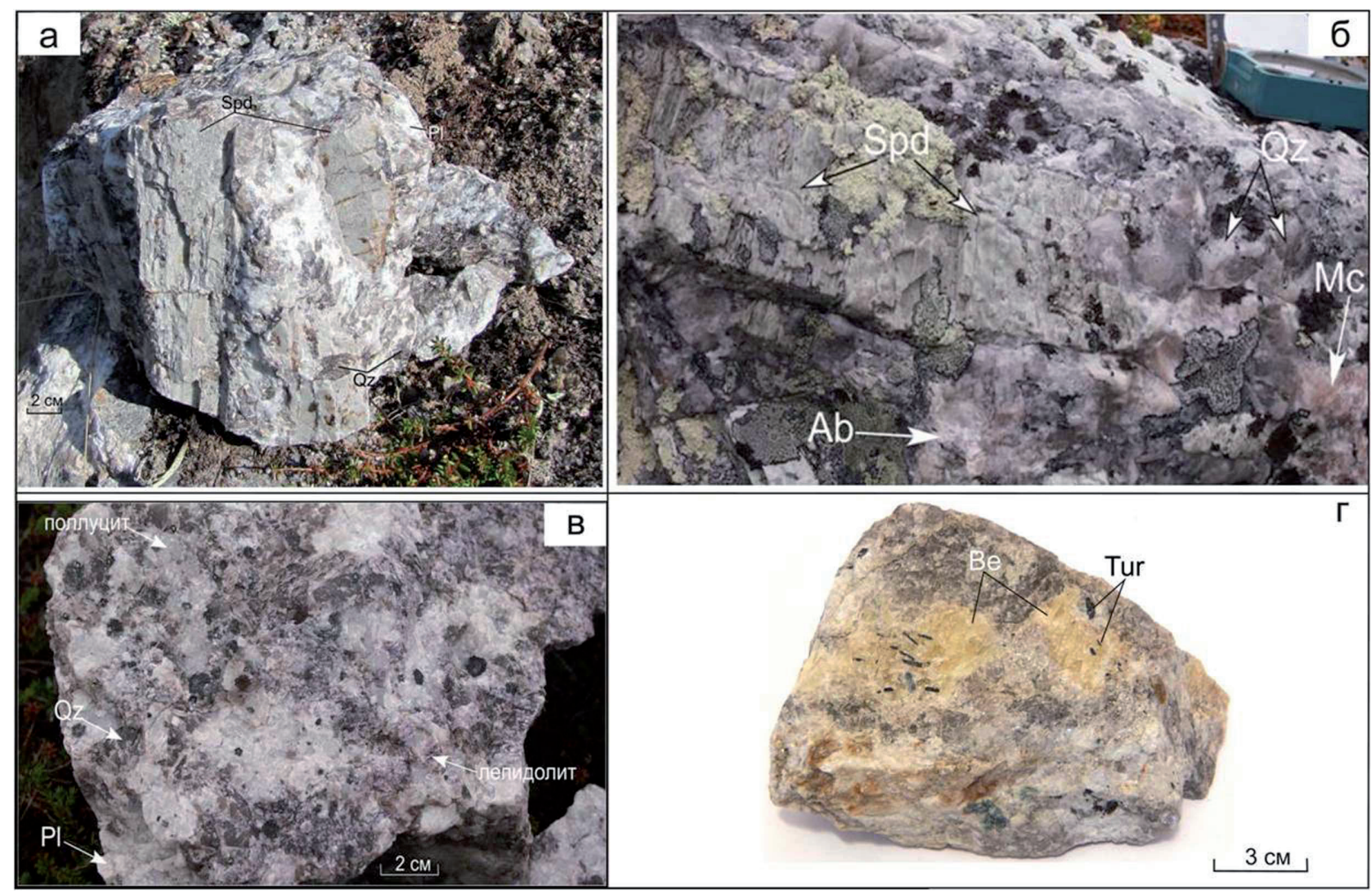

Рис. 2. Редкометалльные пегматиты КРПП (месторождения: а - Колмозерское; б - Полмостундровское; в - Васин-Мыльк; г - Шонгуйское); Ab - albite, Be - берилл, Mc - микроклин, Pl - плагиоклаз, Qz - кварц, Spd - сподумен, Tur - турмалин.

Fig. 2. Rare-metal pegmatites of the Kola rare-metal pegmatite belt (deposits: a - Kolmozero, 6 - Polmostundra, В - Vasin-Mylk; г - Shongui); Ab - albite, Be - beryl, Mc - microcline, Pl - plagioclase; Qz - quartz, Spd - spodumene, Tur -tourmaline.

сутствует. Структурно-минеральные разновидности пегматитов (комплексы, агрегаты) слагают полосы, линзы и участки, согласные с простиранием жил. Жилы секутся дайками габбродолеритов и пикритов (Мультимедийный..., 2001; Коровкин и др., 2003).

Пегматитовые поля Охмыльк, Олений хребет и Васин-Мыльк расположены в зеленокаменном поясе Колмозеро-Воронья в его юго-западной краевой части рядом друг с другом (рис. 1) и объединяются некоторыми авторами в единое Вороньетундровское пегматитовое поле. Эти три пегматитовых поля включают более 100 пегматитовых жил, более половины которых несут Be-Ta-Nb-Li минерализацию, а также месторождения Cs и Та (Охмыльк), Та (Олений хребет) Cs (Васин-Мыльк). Основная часть пегматитовых жил, включая рудоносные, находится в непосредственной близости от юго-западной тектонической границы зеленокаменного пояса Колмозеро-Воронья (рис. 1).

Месторождение Васин-Мыльк является самым крупным месторождение цезия в России, занимает площадь $450 \times 250$ м и представлено тремя жилами редкометалльных пегматитов. Жилы имеют длину от 70 до 250 м при видимой ширине выхода от 3 до 15 м и секут амфиболиты полмостундровской свиты зеленокаменного пояса Колмозеро-Воронья. Возраст редкометалльных пегматитов определен в $2454 \pm 8$ млн. лет (Кудряшов и др., 2015), который, как и возраст колмозерских редкометалльных пегматитов $2315 \pm 10$ млн. лет (Морозова и др., 2017), указывает на их образование во время раннепалеопротерозойского рифтинга. Строение одной из жил - симметрично-зональное, однако симметрия часто нарушается изменением мощности зон вблизи лежачего и висячего бока жилы или выклиниванием зон по простиранию жилы. Рудные минералы представлены поллуцитом, лепидолитом, сподуменом и минералами группы колумбита (рис. 2 в). Важно подчеркнуть, что месторождение Васин-Мыльк является перспективным в отношении лития и тантала (Мультимедийный..., 2001; Пожиленко и др., 2002).

Шонгуйское ПП расположено к Ю-3 от зоны сочленения Мурманской и Кольской провинции (рис. 1 а) в амфиболитах, слагающих пластообразное тело длиной до 60 км и шириной до 7 км в гли- 
ноземистых гнейсах Кольской провинции (Мультимедийный..., 2001). Это поле включает Шонгуйское месторождение редкометалльных пегматитов с рудоразборным бериллом (рис. 2 г), пегматиты c Ве-Та минерализацией и безрудные пегматиты. Месторождение включает пять жил при длине самой крупной жилы $\sim 750$ м и мощности $\sim 30$ м.

\section{Выводы}

Кольский редкометалльный пегматитовый пояс, как и все пояса редкометалльных пегматитов мира, включает редкометалльные месторождения, редкометалльные пегматиты и безрудные пегматиты. Редкометалльные месторождения лития КРПП локализованы рядом с тектоническими границами зоны сочленения архейских Мурманской и Кольской провинций. Эта зона представляет собой транскоровую зону сдвигового течения архейского заложения, испытавшей активизацию в палеопротерозое. Она служила каналом для циркулирования рудоносных флюидов, которые сформировали пегматитовые поля и редкометалльные месторождения. Значительная часть этих полей и месторождений находится в краевых частях архейского зеленокаменного пояса Колмозеро-Воронья.

\section{Благодарность}

Авторы выражают благодарность OOO «ТД HALMEK-LITHIUM» и Т.Б. Баяновой за финансирование полевых работ и В.В. Балаганскому за конструктивные замечания и редактирование рукописи.

Исследования выполнены в рамках темы НИР № 0226-2019-0053.

\section{Литература}

1. Гордиенко В.В. Минералогия, геохимия и генезис сподуменовых пегматитов. Л. Изд-во: Недра. 1970. $240 \mathrm{c.}$

2. Загорский В.Е. и др. Крупные поля сподуменовых пегматитов в обстановках рифтогенеза и постколлизионных сдвигово-раздвиговых деформаций континентальной литосферы / Геология и геофизика. 2014. T. 55. № 2. С. 303-322.

3. Загорский В.Е., Макагон В.М., Шмакин Б.М., Макрыгина В.А., Кузнецова Л.Г. Редкометалльные пегматиты. Т. 2. Гранитные пегматиты, Новосибирск. Изд-во: Наука. 1997. 285 с.

4. Земная кора восточной части Балтийского щита. Л. Изд-во: Наука. 1978. 231 с.

5. Коровкин В.А. и др. Недра Северо-запада Российской Федерации. Санкт-Петербург. Изд-во: ВСЕГЕИ. 2003. $754 \mathrm{c}$.

6. Кудряшов Н.М., Лялина Л.М., Апанасевич Е.А. Возраст редкометальных пегматитов месторождения Васин-Мыльк (Кольский регион): результаты геохронологического U-Pb исследования микролита // Доклады АН. 2015. Т. 461. № 4. С. 437-441. DOI: 10.7868/80869565215100205.

7. Кудряшов Н.М. и др. Время формирования редкометалльных пегматитов зоны Колмозеро-Воронья: изотопно-геохимические исследования циркона (SHRIMP RG) из турмалин-мусковитовых гранитов // Основные проблемы в учении об эндогенных рудных месторождениях, новые горизонты. Материалы всероссийской конференции, посвященной 120 -летию со дня рождения выдающегося российского ученого академика А.Г. Бетехтина. М. Изд-во: ИГЕМ РАН. 2017. С. 95-98.

8. Морозова Л.Н. Редкометалльные пегматиты северо-восточной части Кольского пегматитового пояса: геология и геохимия (Кольский полуостров) // Труды XVI Всероссийской (с международным участием) Ферсмановской научной сессии ГИ КНЦ РАН. Апатиты. Изд-во: К\& М. 2019. С. 393-397. DOI:10.31241/FNS.2019.16.079.

9. Морозова Л.Н. и др. Редкометалльные пегматиты Колмозерского литиевого месторождения Арктического региона Балтийского щита: новые геохронологические данные // Вестник Кольского научного центра РАН. 2017. № 1. С. 43-52.

10. Мультимедийный справочник по минерально-сырьевым ресурсам и горнопромышленному комплексу Мурманской области: цифровой информационный ресурс (под ред. Ф.П. Митрофанова, А.В. Лебедева). Апатиты. Изд-во: ГИ КНЦ РАН. 2001.

11. Пожиленко В.И. и др. Геология рудных районов Мурманской области. Апатиты. Изд-во: КНЦ РАН. 2002. $410 \mathrm{c}$.

12. Fractures, Fluid Flow and Mineralization. Geological Society London Special Publication 155. 1999. 328 p.

13. Morozova L.N. The Kolmozero deposit: a unique Li source in the European Arctic of Russia // IOP Conference Series Earth and Environmental Science. 2019. V. 302. № 1. 012047. DOI: 10.1088/1755-1315/302/1/012047. 